DOI: $10.20472 / E F C .2017 .007 .017$

\author{
MIKULAS PICHANIC \\ University of Economics, Prague, Czech Republic
}

ANNA STANKOVA

University of Economics, Prague, Czech Republic

\title{
THE CZECH GOVERNMENT'S STRATEGY FOR FIGHTING INEQUALITY
}

\begin{abstract}
:
Defenders of globalization often argue that, whatever distress it may cause for the rich-world workers, it has been good for poor or less affluent countries. The inequality as measured by the distribution of income between the rich and poor countries, has globally narrowed. But within each country, the story is less pleasing. We may use three different arguments to support this conclusion: 1) differentiation among workers. A-skilled workers in rich countries; B-low skilled workers in rich countries; C-high-skilled workers in poor countries; D-low-skilled workers in poor countries. The new slogan originating in the Silicon Valley works with the "gig economy" and with the appearance of the new workers category - contract workers. 2) growth of crony capitalism (measured by the crony capitalism index). 3) social and economic mobility. The authors came to the conclusion that inequality of workers in the Central European post-communist countries will never reach the income level corresponding to their counterparts of groups A and B in the developed economies of the EU and the inequality in the Czech Republic contrary to the general accepted opinion about egalitarian society has been growing.
\end{abstract}

\section{Keywords:}

Keywords: Globalization, Inequality, Income, Gig Economy, Categories of Workers, Crony Capitalism, Automated Systems

JEL Classification: D60, D31, D33

The paper was processed using means of institutional support for long-term strategic development of science and research of the Faculty FFÚ of the University of Economics, Prague IP 100040. 


\section{Introduction}

Let us start with the most understandable definition of globalization.

„Sourcing capital from where it is cheapest, sourcing talent from where it is best available, producing where it is most cost effective and selling where the markets are without being constrained by national boundaries."-- N. R. Narayana Murthy, Infosys (CNBC, 2014).

Defenders of globalization often argue that, whatever distress it may cause for richworld workers, it has been good for poor or less affluent countries. The data provided by the World Bank support this opinion. (Though one of the most famous opponent of globalization Joseph E. Stiglitz doesn't agree with these argumentation of neo-liberal economists: "Big parts of population segments in the highly developed countries don't enjoy increased participation on profits created through the globalization. In the USA the salary of median male fully employed worker cleaned of inflation is smaller than the corresponding income 42 years ago" (Handelsblatt, 2016, p. 46-47). The same arguments used Bernie Sanders in INY Times (INY Times, 2016. p. 12).

Figure 1: Global wealth inequality

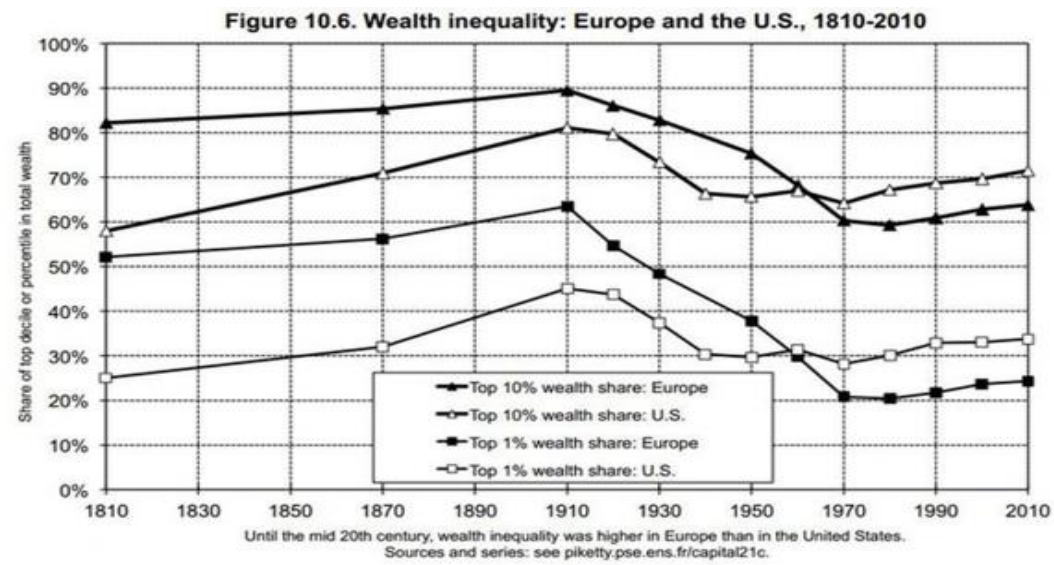

(Source: Piketty, 2014, p.349)

These three statements gave us impetus for formulating a research hypothesis of this paper: "Is the Czech society as egalitarian as it is commonly believed?"

\section{Globalization and its measurable consequences on societies}

\subsection{Gini-coefficient of inequality}

The inequality as measured by the distribution of income between the rich and poor countries has narrowed. But within each country, the story is less pleasing. Globalization in fact resulted in quicker widening inequality in many poorer countries. The Gini-coefficient is the most commonly used measure of inequality. The coefficient varies between 0 , which reflects perfect equality and 1 , which indicates perfect 
inequality. Graphically, the Gini coefficient can be easily represented by the area between the Lorenz curve and the line of equality.

\section{Gini-coefficient of inequality}

$$
G=\frac{\sum_{i=1}^{n} \sum_{j=1}^{n}\left|x_{i}-x_{j}\right|}{2 n^{2} \bar{x}}
$$

- where $\mathrm{x}$ is an observed value, $\mathrm{n}$ is the number of values observed and $\mathrm{x}$ bar is the mean value.

Table 1: Gini coefficient (disposable income, post taxes and transfers), for selected Central European countries and USA, year 2012

\begin{tabular}{|l|l|l|}
\hline \multicolumn{1}{|c|}{ Country } & Gini coefficient & Palma ratio \\
\hline Austria & 0,276 & 0,96 \\
\hline Czech Republic & 0,256 & 0,89 \\
\hline Hungary & 0,29 & 1,03 \\
\hline Poland & 0,298 & 1,08 \\
\hline Slovakia & 0,25 & 0,83 \\
\hline USA & 0,389 & 1,74 \\
\hline
\end{tabular}

(Source: Own adjustment based on OECD data)

\subsection{Eurostat uses different measure of coefficient: Income quintile share ratio (S80/S20 ratio)}

The Gini coefficient is a measure of the inequality of income distribution. It is calculated as the ratio of total income received by the $20 \%$ of the population with the highest income (the top quintiles) to that received by the $20 \%$ of the population with the lowest income (the bottom quintile). More generally, income ratios can be computed for different 'quantiles', a generic term that refers to any specific population proportion. For example, income ratios may be computed on the basis of deciles (1/10 of the population ranked by income), quartiles (one quarter of the population), etc. 
Figure 2: Eurostat Income quintile share ratio (S80/S20)

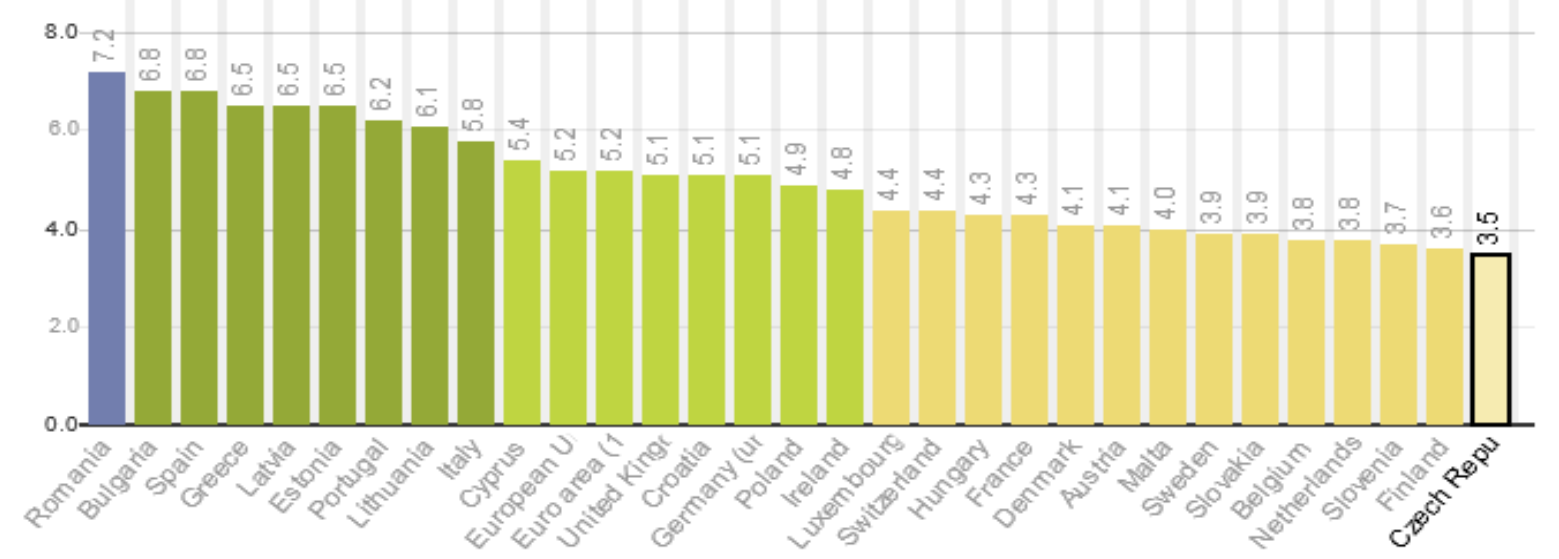

(source: Eurostat)

Income inequality in the CR has stayed in the long period 2004-2014 at the same level of 3.5. We can come to the conclusion that if this level is compared with growth rates of GDP and the growth of average salary in CR from 2004-2014 then the inequality has in the reality increased.

Palma Ratio-The Palma ratio is defined as the ratio of the richest $10 \%$ of the population's share of gross national income divided by the poorest $40 \%$ 's share. It is based on the work of the Chilean economist Gabriel Palma who found that middle class incomes almost always represent about half of gross national income while the other half is split between the richest $10 \%$ and poorest $40 \%$, but the share of those two groups varies considerably across countries. The Palma ratio addresses the Gini index's over-sensitivity to changes in the middle of the distribution and insensitivity to changes at the top and bottom, and therefore more accurately reflects the income inequality's economic impacts on society as a whole. Palma has suggested that distributional politics pertains mainly to the struggle between the rich and poor, and who the middle classes side with. Looking at the situation in pre-election campaigns in the USA and the middle class standing in China and other countries, supports the use of the Palma ratio rather than Gini coefficient showing how much wealth is accumulated by top $10 \%$ of country billionaires. (Palma, 2006)

The professional publications describe two of the major schools of thought on income inequality. The American and Chinese views. The Chinese perceive inequality corresponding to characteristics of high power- distance countries. The greatest divide in both income and opportunity is between the rural and urban areas. The Gini coefficient in China has risen to almost 0.7. (FT, 2016) The American approach says that income inequality is not as important as social and economic mobility. If everyone has the opportunity to make more money and increase their own income and social standing, then your income in relation to others will only be as limited as you let it be, and large gaps are okay because it's the meritocracy that punishes people who don't work as hard. 
One of the mainly perceived ways to fix inequality is through the government and legislation. Many of the ways America combats this social mobility is through legislation banning unequal hiring practices and discrimination. The capitalist system is supposed to combat inequality as a functioning meritocracy, because ideologically there would be no racism or sexism, as those who do the best work should be the ones doing the work, nothing else should be considered. However, this view gets in trouble when people with more money can spend it on better schools, getting better skills to be better at the jobs, and therefore leads to inequality, promoting individual families and communities, creating dynasties. An article in The Economist entitled "Mobility, measured" (The Economist, 2014), stated the five barriers to social mobility (which are the things to be addressed in order to properly combat inequality) are residential segregation, quality of schooling, family structure, "social capital" (interaction with groups), and inequality (pre-existing income inequality). The conflicting argument is generally the European point of view, which says that regardless of what is put in, income inequality should be addressed. The rich should only be allowed to be so rich and the poor should only be allowed to be so poor, so that social balance could be maintained. This argument is much more straightforward and easier to address on paper. The main tool to combat this kind of inequality is taxation, taking money from those who are richest and giving it to those who are poorest in order to keep income inequality at a minimum level. However, the issue with this is one of incentive. What's the point of getting richer if the government is just going to take more and more of your money? This especially creates an issue when you are free to move your money across the borders, and the richest leave the country for tax reasons and capital leaves your country.

\section{Analyzing the situation in the $C R$ we may use three different factors to explain the development of inequality}

\subsection{The categories of workers}

Prof. Eric Maskin of Harvard University (Kremer, Michael, and Eric Maskin. "Globalization and inequality." 2006; presented as well at the Lindau Meeting on Economic Sciences, recited from The Economist, August $23^{\text {rd }}, 2014$ p. 64) presented the problem of "matching". He differentiated workers in four categories. A-skilled workers in rich countries; B-low skilled workers in rich countries; C-high-skilled workers in poor countries; D-low-skilled workers in poor countries.

In the first wave of globalization the workers of the class $C$ and $D$ worked together. But the new wave of globalization based on global connectedness (see: Index of connectedness), has distorted the pairings. The high skilled workers in poor countries work (due to the outsourcing of some part of up-stream industries, i.e. the semifinished products that account for almost two thirds of the world trade) more easily with low skilled workers in rich countries, thus creating the new segment of society in poor countries. The multinationals in developing countries pay higher wages above 
the norm of the country. The result is higher demand and productivity for skilled poorcountry workers. As an example we can take shared services in the Czech Republic, located in the two biggest cities- Prague and Brno. There are 15000 employees in the "shared services centers" in Brno working for more than 40 multinationals, providing services in accounting, logistics and call centers. Even bigger number of employees work for shared services centers or multinational companies in Prague. Prague with 32000 workers makes almost $50 \%$ of the whole employment. (HN 17-19. červen 2016). But work in outsourced production or services and call-centers managed big multinational companies is considered as unskilled anyway by rich countries standards. The skilled workers in poor countries therefore cannot "match" with skilled workers in rich countries. The least skilled workers in poor countries are losing not only access to skilled workers jobs in rich countries but even the access to skilled workers in their own economies. It is evident that globalization does not boost the wages for all. And therefore it results in growing income inequality.

Is there a new category of workers emerging - the contract workers? The new slogan originating in the Silicon Valley works with the "gig economy". The is the result of two factors -a) the advance of technology: researchers at the UK 's Oxford Martin business school estimate that almost half of all US jobs are at risk of being automated in the next two decades, and b) the changing character of work. A couple of years ago it was assumed that a "job" meant working for a company on a fixed schedule. Many workers in the developed world no longer fit in that category. Although they work for a company they have self-employed status and do irregular hours. Their work consists of a series of short-term jobs coordinated through a mobile app. These alternative represents the proportion of high skilled workers who don't have traditional jobs, who work as independent contractors instead, through temporary services or on-call. So far we can see it in the rich most-developed economies like the US. The number of Americans using these alternate work arrangements rose to 9.4 million from 2005 to 2015. The big question for the next decade is whether the shift to contractor work will make the similar shift in regular employment in developing countries or whether it represents one-time thing. In case of copying the trend of developed countries the authors see the biggest implications for Central European countries on social insurance. Employers in the Central European countries traditionally take the burden of protecting the workers from the things that can go wrong in life. They provide health insurance and social insurance. They pay for compensation for people who are injured on the job, unemployment insurance and benefits who are laid off.

\subsection{The volume of transferred profits of MNC's from the Czech Republic}

The Czech economy is an open economy and hundreds of MNC's operate either directly or through their branches on the Czech market. Around 400 billion crowns outflows yearly from the Czech Republic (represents approximately $10 \%$ of the Czech GDP and has almost reached the level of government spending on social issues in 2015 of $12.6 \%$ ). This money could be used in government policies aiming to deal with growing inequality caused due to two other factors described in this contribution. 


\subsection{The crony capitalism (expressed in crony capitalism index)}

Two years ago The Economist constructed an index of crony capitalism. The index aims to measure trends in the number of economic rent-seekers. The assumption is that because of the favorable political policies set by the government officials, the tycoons are increasing their wealth and interest. As a result, they get a larger part of worker's share of national income, instead of generating more wealth for the whole society. In some extreme cases, some favored suppliers are influential on the establishment and application of the business-impacting laws, and citizens pay the tax for purchasing the overpriced products supplied by the favored corporations. Ten of the industries that are susceptible to monopoly or require licensing or highly depend on the government have been selected: casinos: coal; defense; deposit-taking banking and investment banking; infrastructure and pipelines; ports; airports; real estate and construction; steel and other metals; utilities and telecoms services. Results can be achieved from the ratio of billionaire's wealth to GDP in their own countries. The higher ratio of billionaires' wealth to GDP indicates higher possibility of suffering from crony capitalism.

Using the methodology of The Economist (The Economist, May 7th-13th, 2016, p. 46) we can calculate the values for the Czech Republic. We will be using two different data:

a) taken from Forbes rankings for 2015. GDP of the Czech Republic in $2015=4477$ billion crowns, the wealth of 60 richest billionaires amounts to 846.9 billion crowns. The billionaire's wealth as \% of GDP 2015:

$$
\text { 846.9: } 4477=18,92 \% \text {. }
$$

By comparing the result with the ranking calculated in The Economist (May 7th, 2016) (There is only one Central European country, Poland, with the result of $2 \%$ ) we can state that impact of crony capitalism in the $\mathrm{CR}$ is much higher than in Poland.

b) we can even use alternative measurement by taking the wealth of dollars millionaires (Dollars millionaires are defined as segment of the society, who invested amount of one or more millions USD, not including durable goods of personal consumption. The number of people included in this segment in the CR according to Forbes makes 23200 persons. (Týden CZ, 2016) We can take the current exchange rate:

USD $/ C Z K=1 U S D=24.2$ CZK, $23200 \times 24,2=561$ bill. CZK

$561: 4477=12,53 \%$

Suppose the millionaire's group doesn't include the billionaires group of the 60 richest (Forbes, 2015). If we put both groups together and sum up their wealth:

$846.9+561=1407.9$ billion CZK.

$1407.9: 4477=\mathbf{3 1 . 4 5} \%$ 


\section{How can we combat inequality in the Czech Republic?}

\subsection{Attracting FDI into industries with higher added values}

By creating incentives for attracting FDI into the Czech economy there is necessity for the Czech government to formulate conditions requiring that at least some parts of investment went to higher value-added branches or to the creation of centers of excellence, thus providing bigger options for career and employment for workers of category C. In the Czech Republic the number of university graduates $(21,1 \%$ of all employed people) can be considered as formally qualified for the job in group C. (Doležalová, 2015)

\subsection{Raising the minimum wage (monthly or per hour)}

To enhance the minimum wage is one of the most direct and efficient ways to address inequality. While average workers' wages grow by hardly copying inflation rates, the salaries for those at the top have skyrocketed. But increasing the minimum wage is not just a matter of equity or means of fighting inequality. It is also the basic condition for improving the economy. Raising the minimum wage would put money into the pockets of workers who are expected to spend their money directly at businesses in their communities. Just as importantly, research shows that a higher minimum wage could positively affect the economic growth by prompting more human-capital development, which can also help to lower income inequality. An example of the introduction of minimum wages in Germany: Since 2015 Germany has a minimum wage of $8.50 € /$ hour. And still Germany has one of the lowest unemployment in the EU integration. The current level in the CR of 407 EUR monthly doesn't contribute to the elimination of inequality.

\subsection{Strengthen and protect workers}

Moreover collective bargaining rights should be amplified to help and to give workers the influence they need, to bargain for better wages and benefits.

\subsection{Increase access to high-quality preschool}

Children of low-income employees are falling behind before they even step foot into kindergarten and can be months or even years behind children from the same age but from wealthy families. Researchers estimate that half of the performance gap in high schools can be attributed to children's experiences before age 5. Differences between children arise early, leading to large gaps in key skills, such as vocabulary. Preschool programs can help children gain four months of additional learning, and the highestquality programs have been shown to help children gain an additional year of learning. Children who attend high-quality preschools have positive outcomes throughout their lifetime. They are more likely to graduate from the high school, attend college and university, and consequently earn higher wages as adults. The newest proposals of 
government (from September 2017) the obligatory visit of preschool facilities for children of 5 years age can be considered as the move in the right direction.

\subsection{Introduce and practice apprenticeships}

Apprenticeships is a form of paid worker training, so you work for a company and simultaneously you attend school. This system will significantly boost workers' lifetime wages and create pathways to well-paying careers for unemployed young workers. Many countries already rely on apprenticeships as a central tool for developing a competitive workforce. Apprenticeships profit workers by connecting them with a paid job, raising their lifetime wages, and offering a post-secondary education with little or no debt.

But it has not only advantages for the trainees. Employers who sponsor apprentices gain skilled workers, reduce employee turnover, and enhance productivity. Apprenticeships can help businesses address skilled-labor shortages at a time when many employers are reporting that they cannot find skilled workers. In the United States, 98 per cent of businesses sponsoring apprenticeships report that they would recommend them.

\subsection{Offer universal paid family leave}

Income inequality directly contributes to the different abilities of parents to care for their children and provide them with the kind of living environment most beneficial to healthy growth, success in school, and success in the workplace. Not only can wealthier parents afford high-quality child care, but, disproportionately, they have access to flexible schedules, paid leaves, and paid sick days. The children profit from more parental time, which leads to acquiring larger vocabularies, paying more attention to schooling and homework, greater attendance at parent-teacher conferences, and more and better health care.

\subsection{Taxation}

One of the most disputed tools for fighting the inequality is tax system. Tax and benefit system is one of the typical forms of government intervention. The government could charge the rich a heavier tax burden and transfer the revenue to the poor. It can be used in welfare like health care, education, public schooling, transportation subsidies and poor communities' development. In terms of taxation, there are horizontal and vertical systems that promote equity in different ways. Most governments try to adopt both horizontal and vertical equities. The horizontal equity suggests that everyone should be taxed the same rate while vertical equity means that people should pay differently according to their ability and earnings. (DUŠEK, L., KALÍŠKOVÁ, K., \& MÜNICH, D. 2015). 


\subsection{Crony capitalism}

The data calculated for the $\mathrm{CR}$ do not support the general opinion about egalitarian society. With the values $18.92 \%$ or alternatively $12,53 \%$ the CR would be placed more to the group of countries such as Germany or the USA that will have to implement measures against cartels.

\section{Conclusions}

The authors came to the conclusion that inequality of workers in the Central European post-communist countries will never reach the income level corresponding to their counterparts of groups A and B in the developed economies of the EU and the inequality in the Czech Republic contrary to the general accepted opinion about egalitarian society has been growing. The analysis of worker's share on national income in the Czech Republic in the light of three specific factors has shown the rise of inequality, regardless of the steady growth of average salary and the growth of GDP. This conclusion is supported by the calculated crony-capitalism index figures. As long as the inflow of FDI into the Czech economy goes mainly into industries with the low added value and not in the centers of excellence, the chances of eliminating inequality of workers of group $\mathbf{C}$ are unrealistic.

\section{References}

BLANCHARD, E., \& WILLMANN, G. (2016). Trade, education, and the shrinking middle class. Journal of International Economics, 99, 263-278. Retrieved September 07, 2016, from http://www.sciencedirect.com/science/article/pii/S0022199615001543

DOLEŽALOVÁ, G. (2015). A nalýza profesní struktury pracovních sil a struktury absolventů z pohledu sféry vzdělávání - 2014 [PDF]. Praha: Národní ústav pro vzdělávání, školské poradenské zařízení a zařízení pro další vzdělávání [Online]. Available:

http://www.nuv.cz/uploads/Vzdelavani a TP/Struktura prac sil 2014 final pro www.pdf

DUŠEK, L., KALÍŠKOVÁ, K., \& MÜNICH, D. (2015). The Poor or the Kids? Distributional Impacts of Taxes and Benefits Among Czech Households. Prague Economic Papers, 2015(5), 1-16

Eurostat. Your key to European statistics. (n.d.). Retrieved September 15, 2016, from http://ec.europa.eu/eurostat/web/gdp-and-beyond/quality-of-life/s80s20-income-quintile

Forbes. 50 nejbohatších Čechů. (n.d.). Retrieved September 07, 2016, from http://www.forbes.cz/miliardari/\#tab

JANSKÝ, P., KALÍŠKOVÁ, K., \& MÜNICH, D. (2016). Does the Czech Tax and Benefit System Contribute to One of Europe's Lowest Levels of Relative Income Poverty and Inequality?. Eastern European Economics, 54(3), 191-207.

KEARNEY, M., \& LEVINE, P. (2014). Income Inequality, Social Mobility, and the Decision to Drop Out of High School. doi:10.3386/w20195 [Online] Retrieved September 15, 2016 from: http://mba.americaeconomia.com/sites/mba.americaeconomia.com/files/w20195.pdf

KOCHAN, T. A., \& RIORDAN, C. A. (2016). Employment relations and growing income inequality: Causes and potential options for its reversal. Journal of Industrial Relations, 58(3), 419-440. doi:10.1177/0022185616634337. [Online] Retrieved September 15, 2016 from: http://mitsloanphp.s3.amazonaws.com/iwer/wp-content/uploads/2016/01/Kochan.Riordan JIR.Inequality.pdf 
KRUEGER, A. (2002). Why crony capitalism is bad for economic growth. Crony capitalism and economic growth in Latin America: theory and evidence, 1-23. Retrieved September 15, 2016 from: http://www.hoover.org/sites/default/files/uploads/documents/0817999620 1.pdf

MITCHELL, T., \& PARKER, G. (2016, September 5). G20 takes up global inequity challenge. Financial Times, p. 2.

Mobility, measured. (2014, February 1st). The Economist, 410 (8872), 35.

OECD Database. Income Distribution and Poverty. Retrieved September 15, 2016, from https://stats.oecd.org/Index.aspx?DataSetCode=IDD

Our crony-capitalism index. (2016, May 7th). The Economist, 419 (8988), 46-48.

OYVAT, C. (2016). Agrarian Structures, Urbanization, and Inequality. World Development, 83, 207-230. Retrieved September 15, 2016, from: http://citeseerx.ist.psu.edu/viewdoc/download?doi=10.1.1.636.9562\&rep=rep1\&type=pdf

PALMA, J. G. (2006). Globalizing Inequality: 'Centrifugal' and 'Centripetal' Forces at Work. ST/ESA/2006/DWP/35, DESA Working Papers No. 35. New York: United Nations Department of Economic and Social Affairs. [Online] Retrieved September 15, 2016 from: http://ww.rrojasdatabank.info/wp35 2006palma.pdf

PIKETTY, Thomas a Arthur GOLDHAMMER. Capital in the twenty-first century. ISBN 9780674430006.

SANDERS, B. (2016, June 30th). Democrats have to wake up. International New York Times, p. 12

SORRENTINO, N. (2016). Corporate Welfare: Crony Capitalism That Enriches the Rich. 21(1), 147150. [Online] Retrieved September 15, 2016 from: http://ar9zk7pw9f.scholar.serialssolutions.com/?sid=google\&auinit=N\&aulast=Sorrentino\&atitle=C orporate+Welfare:+Crony+Capitalism+That+Enriches+the+Rich\&title=The+independent+review+ (Oakland, + Calif. $) \&$ volume $=21 \&$ issue $=1 \&$ date $=2016 \&$ spage $=147 \&$ issn $=1086-1653$

STIGLITZ, J. (2016, August 19th). Die neuen Unzufriedenen der Globalisierung. Handelsblatt, 46- 47.

Týden. (2016). V Česku přibývá dolarových milionářů. Retrieved September 07, 2016, from http://www.tyden.cz/rubriky/byznys/svet-miliardaru/v-cesku-pribyva-dolarovychmilionaru_392232.html

Why globalisation is not reducing inequality within developing countries. (2014, August 23rd). The Economist, 412 (8901), 64. 